\title{
IDENTIFIKASI SPESIES IKAN BERDASARKAN KONTUR OTOLITH MENGGUNAKAN METODE OTSU DAN BACK PROPAGATION NEURAL NETWORK
}

\author{
Heri Susanto ${ }^{1}$, Jamal ${ }^{2}$ \\ Program Studi Sistem Informasi \\ Akademi Manajemen dan Informatika Taruna Probolinggo \\ Jl. Raya Leces No. A3 Leces Probolinggo Jawa Timur \\ Telp. 0335-681497 \\ E-mail: herisusanto@amik-taruna.ac.id ${ }^{1}$, jamal@amik-taruna.ac.id ${ }^{2}$
}

\begin{abstract}
ABSTRAKS
Otolith merupakan organ yang sangat penting, karena melalui otolith dapat diketahui jenis ikan, pertumbuhan, lingkungan, serta sejarah kehidupannya, misalnya, umur, reproduksi, dan migrasi. Dengan semakin canggihnya komputer dan pengolahan di bidang citra, diharapkan kemampuan mengidenifikasi jenis ikan yang dimiliki oleh manusia bisa diadopsi dan diterapkan pada perangkat komputer. Threshold adalah sebuah teknik penting dalam aplikasi segmentasi citra. Hal mendasar dari threshold adalah menentukan nilai batas optimal dari citra keabuan, untuk memisahkan antara obyek dengan latar belakang. Metode Backpropagation Neural Network, merupakan metode klasifikasi yang handal untuk perhitungan yang rumit dengan waktu komputasi lebih sedikit, dan mampu memberikan nilai akurasi yang tinggi. Untuk keperluan segmentasi citra menggunakan metode Otsu karena metode ini merupakan metode paling berhasil untuk image thresholding. Proses klasifikasi untuk pengenalan spesies ikan berdasar otolith menggunakan metode Backpropagation Neural Network. Hasil eksperimen diperoleh akurasi sebesar 95\% lebih tinggi dibanding metode Discriminant Analysis yang memiliki akurasi sebesar $92 \%$.
\end{abstract}

Kata Kunci: Otolith; Otsu; Backpropation Neural Network

\begin{abstract}
Otoliths are very important organs, because through them, fish species, growth, environment, and life history can be identified, for example, age, reproduction and migration. With increasingly sophisticated computers and image processing, it is hoped that the ability to identify the types of fish owned by humans can be adopted and applied to computer devices. Threshold is an important technique in image segmentation applications. The basic thing about the threshold is to determine the optimal limit value of the gray image, to separate objects from the background. The Backpropagation Neural Network method is a reliable classification method for complex calculations with less computation time, and is able to provide high accuracy values. The Otsu method is used for image segmentation purposes because this method is the most successful method for image thresholding. The classification process for the introduction of fish species based on otoliths uses the Backpropagation Neural Network method. The experimental results obtained an accuracy of 95\% higher than the Discriminant Analysis method which has an accuracy of $92 \%$.
\end{abstract}

Keywords: Otolith; Otsu; Backpropation Neural Network

\section{PENDAHULUAN}

\subsection{Latar belakang}

Berdasarkan hasil sensus kehidupan laut pada tahun 2013 di seluruh dunia terdapat lebih dari 23.000 bahkan mendekati 25.000 spesies, dimana dua belas persen $(12 \%)$ merupakan jenis spesies ikan $(2.760$ - 3.000). Dari jumlah spesies tersebut baru 1.200 yang sudah diberikan diskripsi secara formal (Miloslavich, 2012). Dibutuhkan seorang ahli di bidang biota laut untuk bisa melakukan identifikasi, disertai suatu alat bantu untuk mengenali jenis-jenis ikan tersebut.

Pengenalan ikan adalah cara mengidentifikasi ikan berdasarkan ciri-ciri khusus, bisa melalui gambaran bentuk, pola tubuh ikan, warna ataupun ciri-ciri lainnya. Dengan semakin berkembang dan meluasnya kemampuan komputer, kemampuan mengidentifikasi ikan oleh manusia bisa ditingkatkan dengan bantuan perangkat komputer. Terjadi peningkatan yang signifikan dalam studi sistem identifikasi di bidang biologi berdasarkan morfologi (penampakan bentuk) maupun taksonomi (persamaan dan pembedaan sifatnya) secara otomatis, terutama disebabkan oleh peningkatan kemampuan pemrosesan dan pengolahan menggunakan perangkat komputer(Reichenbacher, 2007).

Lombarte dan Castellon (1991), mengamati bahwa setiap spesies ikan memiliki otolith dengan karakteristik tertentu (bentuk dan ukuran), dimana morfologi otolith dan morfometri telah dipelajari untuk mengidentifikasi spesies dan fauna fosil 
(Reichenbacher, 2007), serta menentukan jenis makanan spesies dari kandungan isi perutnya(Fitch \& Brownell, 1968)(Parisi-Baradad \& Manjabacas, 2010).

Lebih penting lagi adalah kenyataan bahwa otolith bertindak sebagai data logger alami, yang berisi rekaman informasi dari ikan hidup terkait dengan pertumbuhan dan lingkungan mereka(Kalish, 1991)(Campana, 1999). Informasi ini, meliputi usia dan pertumbuhan, serta pola pergerakan dan interaksi habitat, yang dapat digunakan untuk menjelaskan ekologi, demografi atau sejarah kehidupan, dan telah menjadi kepentingan mendasar dalam manajemen ikan dan perlindungan spesies(Soria \& Baradad, 2012).

Otolith adalah sekumpulan calcium carbonate yang terletak di tulang dalam dari telinga ikan. Otolith ini menyimpan sebuah histori kehidupan dan lingkungan yang merekontruksi parameter lingkungan seperti temperatur dan salinitas (kadar garam). Otolith merupakan organ yang sangat penting, karena melalui otolith ini dapat diketahui jenis ikan, pertumbuhan dan lingkungan, serta sejarah kehidupannya, misalnya, umur, reproduksi, dan migrasi (Panfili, de Pontual, Troadec, \& Wright, 2002). Penelitian tentang otolith merupakan topik yang menarik terbukti sudah dilakukan penelitian sejak tahun 1968 oleh John E. Fitch dan Robert L. Brownell dari USA, hingga tahun 2016 oleh Nima Salimi dari Malaysia masih melakukan penelitian tentang otolith ini.

\subsection{Referensi}

Hasil penelusuran dari penelitian terdahulu dapat dirangkum dalam tabel 1 berikut:

Tabel 1: Daftar Penelitian terkait vision. Pada pengenalan pola, pengolahan citra antara lain berperan untuk memisahkan objek dari latar belakang secara otomatis (segmentasi). Selanjutnya, obyek akan diproses oleh pengklasifikasi pola. Sebagai contoh, sebuah obyek buah bisa dikenali sebagai jeruk, apel, atau pepaya(Abdul Kadir, 2013).

\section{Perbaikan Citra pada Domain Spasial}

Istilah spasial yaitu perbaikan yang berbasis pada manipulasi nilai piksel secara langsung. Pada penelitian ini, digunakan filter Laplacian of Gaussian(LoG) sebagai operator untuk perbaikan pada domain spasial. Operator LoG dihasilkan dengan persamaaan (1)(Abdul Kadir, 2013).

$$
\operatorname{LoG}\left(y_{0} x\right)=\frac{1}{\sigma^{2}}\left[\frac{x^{2}+y^{2}}{\sigma^{2}}-2\right] e^{\frac{-\left(x^{2}+y^{2}\right)}{2 \sigma^{2}}}
$$

Dimana, $\mathrm{x}$ dan y adalah koordinat dan $\sigma$ merupakan konstanta. Untuk menghasilkan citra yang terfilter,kemudian menerapkan kernel LoG untuk konvolusi pada citra input. Konvolusi citra diterapkan menggunakan persamaan (2).

$$
\begin{aligned}
& g(y, x)=\sum_{p=-m 2}^{m 2} \sum_{q=-n 2}^{n 2} h(p+m 2+1, q+n 2+ \\
& \text { 1) } f(y-p, x-q)
\end{aligned}
$$

\section{Segmentasi Citra}

Segmentasi citra merupakan proses yang ditujukan untuk mendapatkan obyek-obyek yang terkandung di dalam citra atau membagi citra ke dalam beberapa daerah dengan setiap obyek atau daerah memiliki kemiripan atribut. Pada citra yang mengandung hanya satu obyek, obyek dibedakan dari latar belakangnya.

\begin{tabular}{|l|l|l|l|l|}
\hline No & \multicolumn{1}{|c|}{ Peneliti/Tahun } & \multicolumn{1}{|c|}{ Bidang Kajian } & \multicolumn{1}{c|}{ Metode } & \multicolumn{1}{c|}{ Hasil } \\
\hline 1. & $\begin{array}{l}\text { S.O. Ogunlana et.al., } \\
2015[19]\end{array}$ & $\begin{array}{l}\text { Pengenalan dan klasifikasi } \\
\text { kkan berdasar pencocokan } \\
\text { kontur }\end{array}$ & $\begin{array}{l}\text { Klasifikasi: ANN, K-NN } \\
\text { dan K-Means Clustering. }\end{array}$ & $\begin{array}{l}\text { Akurasi } \\
79 \%\end{array}$ \\
\hline 2 & $\begin{array}{l}\text { Wijanti Nurul } \\
\text { Khotimah etal., 2013 } \\
{[17]}\end{array}$ & $\begin{array}{l}\text { Pengenalan dan klasifikasi } \\
\text { ikan tuna }\end{array}$ & $\begin{array}{l}\text { Fitur Ekstrasi GLCM. } \\
\text { Klasifikasi: Decission Tree }\end{array}$ & $\begin{array}{l}\text { Akurasi } \\
88 \%\end{array}$ \\
\hline 3 & $\begin{array}{l}\text { YU Xin et al., 2014 } \\
{[18]}\end{array}$ & $\begin{array}{l}\text { Pengenalan dan klasifikasi } \\
\text { ikan berdasar kontur otolith }\end{array}$ & $\begin{array}{l}\text { Principal Component } \\
\text { Analysis (PCA) }\end{array}$ & $\begin{array}{l}\text { Akurasi } \\
84 \%\end{array}$ \\
\hline 4 & $\begin{array}{l}\text { Parisi Bagdadi et al., } \\
2015[4]\end{array}$ & $\begin{array}{l}\text { Pengenalan dan klasifikasi } \\
\text { ikan berdasar kontur otolith }\end{array}$ & $\begin{array}{l}\text { Klasifikasi k-Nearest } \\
\text { Neighbours }\end{array}$ & $\begin{array}{l}\text { Akurasi } \\
94 \%\end{array}$ \\
\hline 5 & $\begin{array}{l}\text { Nima Salimi etal., } \\
2016[10]\end{array}$ & $\begin{array}{l}\text { Pengenalan dan klasifikasi } \\
\text { ikan berdasar kontur otolith }\end{array}$ & $\begin{array}{l}\text { Fitur Ekstraksi STFT dan } \\
\text { Klasifikasi Discriminant } \\
\text { Analysis }\end{array}$ & $\begin{array}{l}\text { Akurasi } \\
92 \%\end{array}$ \\
\hline
\end{tabular}

Pengolahan citra (Image Processing) adalah istilah umum untuk berbagai teknik yang keberadaannya untuk memanipulasi dan memodifikasi citra dengan berbagai cara. Pengolahan citra merupakan bagian penting yang mendasari berbagai aplikasi nyata, seperti pengenalan pola, penginderaan jarak-jauh melalui satelit atau pesawat udara, dan machine
Metode Otsu dipublikasikan oleh Nobuyuki Otsu pada tahun 1979. Metode ini menghitung nilai ambang $\mathrm{T}$ secara otomatis berdasarkan citra masukan. Pendekatan yang digunakan dengan melakukan analisa diskriminan yaitu menentukan suatu variabel yang dapat membedakan antara dua atau lebih kelompok yang muncul secara alami. 
Metode ini menentukan nilai ambang (batas) dengan cara membedakan dua kelompok, yaitu obyek dan latar belakang(Smith et al., 1979), yang memiliki bagian yang saling bertumpukan, berdasarkan histogram. Misalkan citra abu-abu memiliki nilai intensitas ( $i)$ sebagai berikut:

1. Menghitung frekuensi kemunculan masing intensitas $(i)$, maka diperoleh: nghitung probabilitas nilai intensitas $I$ dengan $p(i)=\frac{n_{i}}{N}$

3. Pembobotan pada kedua kelas (obyek dan latar belakang) dihitung dengan rumus sebagai berikut:

$$
\begin{aligned}
& \quad w_{1}(t)=\sum_{i=1}^{t} p(i) \\
& w_{2}(t)=\sum_{i=t+1}^{L} p(i) \\
& \text { dengan memasukkan nilai maka, }
\end{aligned}
$$

4. Hitung Rata-rata kedua kelas melalui rumus

$$
\mu_{1}(t)=\sum_{i=1}^{t-1} i_{i} \frac{p(1)}{W_{1}(t)}
$$

dengan memasukkan nilai maka,

5. Hitung Varians kedua kelas dengan rumus:

$$
\sigma_{1}^{2}(t)=\sum_{i=1}^{t}\left(i-\mu_{1}\right)^{2} \times \frac{p(i)}{w_{1}(t)}
$$

dengan memasukkan nilainya maka,

$$
\sigma_{2}^{2}(t)=\sum_{i=t+1}^{L}\left(i-\mu_{2}\right)^{2} \times \frac{p(i)}{w_{2}(t)}
$$

dengan memasukkan nilainya maka, untuk menentukan nilai threshold (ambang) optimal diperoleh dari nilai $\boldsymbol{\sigma}_{\mathbf{w}}{ }^{2}$ terkecil.

\section{Ekstraksi Fitur (Feature Extraction)}

Ekstraksi fitur adalah suatu kegiatan untuk memperoleh ciri-ciri atau nilai-nilai yang membedakan suatu citra digital terhadapcitra digital yang lain. Fitur dinyatakan dengan susunan bilangan yang dapat dipakai untuk mengidentifikasi obyek. Oleh karenanya Ekstraksi Fitur (Feature Extraction) merupakan bagian yang sangat penting dari analisis citra.

\section{Klasifikasi}

Klasifikasi merupakan salah satu teknik dasar dalam bidang data mining. Teknik klasifikasi diperlukan untuk dapat melakukan pengenalan pola, prediksi nilai, hingga pengambilan keputusan. Pada penelitian ini klasifikasi digunakan untuk pengenalan atau identifikasi ikan berdasarkan kelas dan spesiesnya. Tool yang digunakan adalah software Rapidminer, sedangkan metode yang dipilih adalah Back Propagation Neural Network.

\section{PEMBAHASAN}

Penelitian ini dilakukan dengan cara eksperimen. Diawali dengan pengumpulan data, preprocessing, ektraksi fitur, klasifikasi, dan evaluasi. Tahapantahapan penelitian dapat dilihat pada gambar 1 .

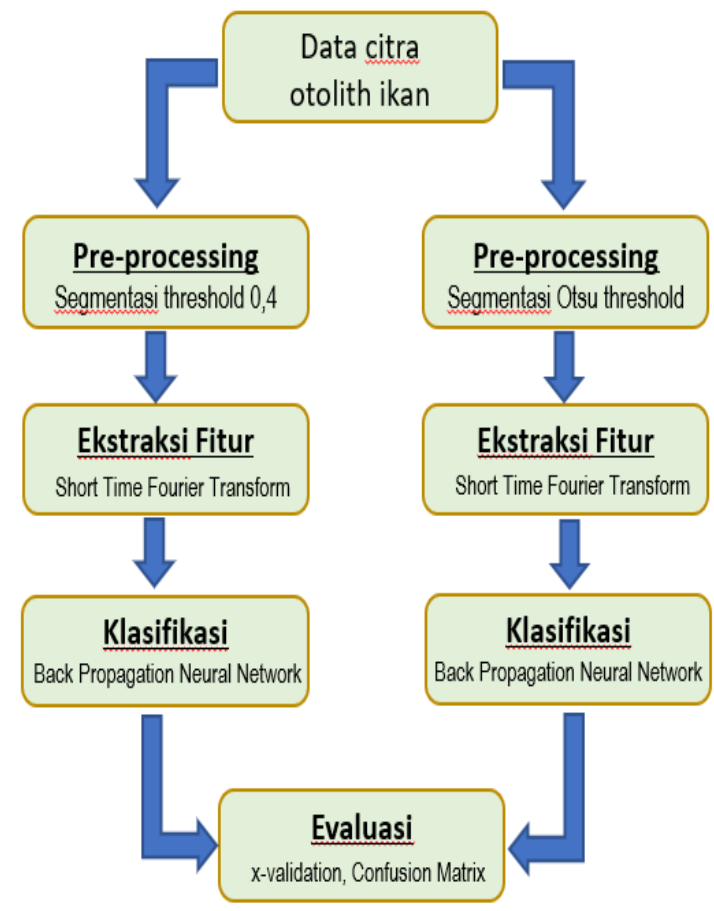

Gambar 1: Tahapan Penelitian

Data citra diperoleh dari University of MalayaInstitute Animal Care and Use Committee (UMIACUC). Data berupa citra dari otolith ikan terdiri dari 3 (tiga) family, yaitu Engraulidae, Sciaenidea, dan Ariidae. Family Sciaenidea terdiri dari 5 (lima) spesies yaitu Dendrophysa Russeli, Johnius Belangerii, Johnius Carouna, Otolithes Ruber, dan Panna Microdon. Family Ariidae terdiri dari 6 (enam) spesies yaitu Nemapteryx Caelata, Arius Maculatus, Cryptarius Truncatus, Hexanemathictys Sagor, Osteogeneiosus Militaris, dan Plicofollis Argyropleuron. Family Engraulidae terdiri dari 3 (tiga) spesies yaitu Coilia Dussumieri, Setipinna Taty, dan Thryssa Hamiltonii. Sehingga secara keseluruhan terdapat 14 spesies ikan.

\subsection{Pengolahan data awal (preprocessing).}

Pengolahan data awal citra dimaksudkan agar diperoleh citra yang lebih baik sehingga hasil proses selanjutnya menjadi lebih baik pula. Adapun tahapannya sebagai berikut:

1. Citra RGB diubah menjadi citra grayscale

Citra RGB atau lebih dikenal sebagai citra berwarna adalah jenis citra yang menampilkan warna dalam tiga layer matrik $\mathrm{R}$ (Red ), G (Green), dan B (Blue). Setiap komponen warna memiliki nilai antara 0 sampai dengan 255. Sehingga warna yang bisa ditampilkan sebanyak 255 × 255 × $255=16.581 .375$ warna. Sedangkan citra grayscale hanya memiliki satu layer matrix saja, yang memiliki nilai antara 0 sampai dengan 255, sehingga tidak bisa menampilkan warna dan yang ada hanyalah aras (derajat) keabuan. Citra warna yang memiliki nilai matrik masing-masing $\mathrm{R}$, G, dan $\mathrm{B}$ dapat diubah menjadi citra 
grayscale, dengan mengambil rata-rata dari nilai $\mathrm{R}, \mathrm{G}$ dan B.

2. Pembersihan Citra dari noise atau derau.

Derau (noise) adalah pixel yang mengganggu kualitas gambar sehingga menyebabkan degrasi dalam citra. Hal ini bisa disebabkan oleh gangguan fisis dari kamera saat pengambilan citra atau akibat kesalahan pada proses pengolahan citra. Tujuan membersihkan derau adalah untuk memuluskan citra sehingga dapat mengurangi derau, yang akhirnya dapat meningkatkan kualitas citra. Metode yang digunakan untuk mengurangi derau adalah Laplacian of Gaussian (LoG).

3. Segmentasi yaitu proses memisahkan obyek dan background.

Citra grayscale diubah menjadi citra biner, bertujuan untuk memisahkan antara obyek dan latar belakang. Teknik pemisahan (segmentasi) citra didasarkan pada 2 nilai derajat keabuan yaitu kesamaan dan ketidaksinambungan antar piksel. Pemisahan citra didasarkan pada perubahan mendadak pada derajat keabuan(Abdul Kadir, 2013).

Segmentasi Citra menggunakan Otsu Threshold.

Segmentasi menggunakan metode Otsu menentukan nilai threshold yang berbeda pada masing-masing citra otolith.

\subsection{Ekstraksi Fitur}

Ekstraksi fitur adalah suatu kegiatan untuk memperoleh ciri-ciri atau nilai-nilai yang membedakan suatu citra digital terhadap citra digital yang lain. Citra otolith dikonversi ke sinyal 1D yang diperoleh dari perhitungan jarak antara tepi citra dengan centroid (titik pusat masa) sebagai fungsi sudut. Kemudian sample sinyal diturunkan menjadi 1000 point dengan interpolasi Fast Fourier Transform (FFT). Metode Short Time Fourier Transform (STFT) diaplikasikan untuk re-sample sinyal yang ditentukan dengan fungsi Gaussian window.(Salimi, Loh, Dhillon, \& Chong, 2016) Dari proses ini diperoleh 16 elemen nilai jarak dan 16 elemen nilai sudut, sehingga secara keseluruhan terdapat 32 elemen (attribut) yang merupakan hasil terbaik untuk klasifikasi.

\subsection{Klasifikasi}

Salah satu metode yang sangat populer adalah Artificial Neural Network (ANN yang merupakan suatu konsep rekayasa pengetahuan yang didesain dengan mengadopsi sistem kerja saraf manusia, di mana pemroses utama sistem saraf manusia berada di otak. Otak manusia berisi berjuta-juta sel syaraf (neurons) yang bertugas untuk memproses informasi. Kemampuan Artificial Neural Network (ANN) didalam melakukan pembelajaran dirancang sedemikian rupa seperti kinerja otak manusia, dimana manusia mempunyai kemampuan dapat memproses informasi, mengingat, dan melakukan perhitungan. Beberapa permasalahan yang dapat diselesaikan dengan Artificial Neural Network (ANN) adalah klasifikasi, prediksi, optimasi dan pengenalan pola.

Backpropagation merupakan salah satu dari model Neural Network yang sangat populer yang mempunyai kemampuan untuk melakukan suatu pembelajaran dalam melakukan prediksi pada data mining(Eko, 2014). Algoritma backpropagation merupakan algoritma pembelajaran yang terawasi (supervised) dengan banyak lapisan (multilayer)(Eko Prasetyo, 2015). Pada pembelajaran supervised, terdapat target yang akan dibandingkan dengan keluaran jaringan. Ketika jaringan input diberi sinyal masukan, sinyal ini diproses ke unit-unit pada lapisan tersembunyi (hidden layer), kemudian diteruskan ke unit-unit pada lapisan keluaran (output layer). Apabila sinyal keluaran pada jaringan tidak sesuai dengan target, maka akan dilakukan langkah mundur pada lapisan tersembunyi (hidden layer) dan dikembalikan ke lapisan masukan (input layer).

\subsection{Arsitektur Backpropagation Neural Network}

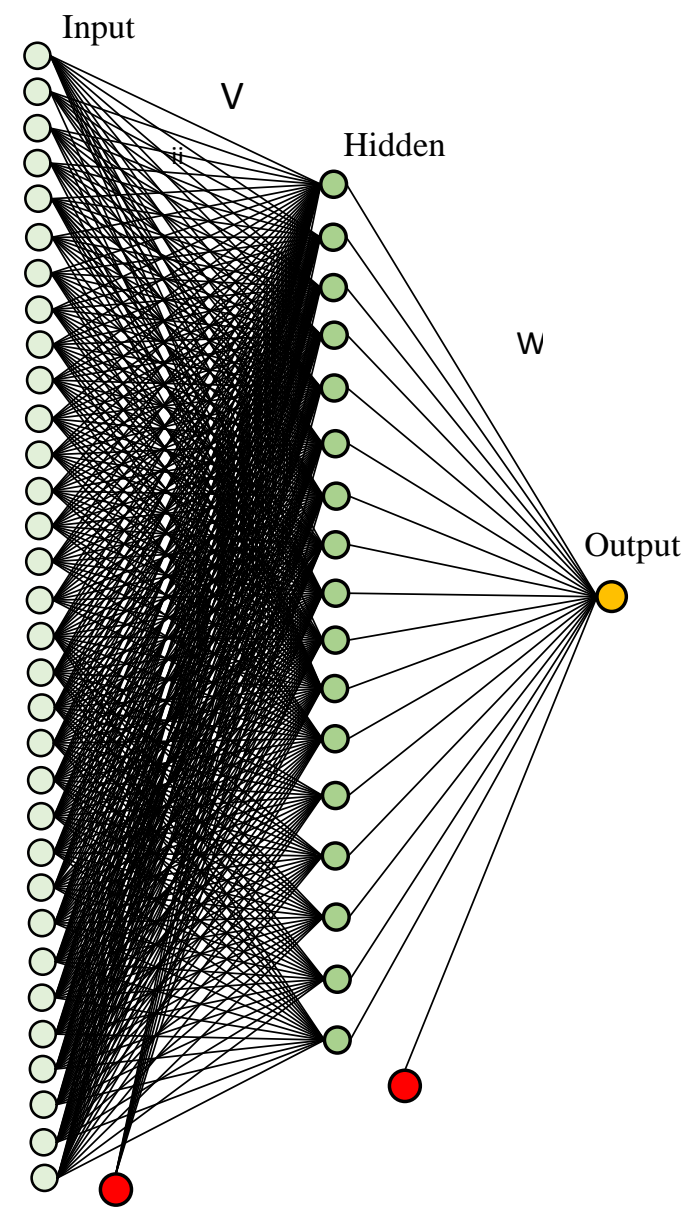

Gambar 2: Arsitektur BackProgapation Neural Network 
Pada arsitektur Back Propagation Neural Network terdapat 3 (tiga) layer yaitu input layer, hidden layer, dan output layer. Adapun software yang digunakan adalah Rapid Miner. Untuk mendapatkan model terbaik Backpropagation Neural Network dilakukan eksperimen dengan cara menguji masing-masing parameter pada Back Propagation Neural Network. Parameter yang diujicobakan adalah nilai-nilai pada hidden layer, learning rate, training cycle, dan momentum.

Berdasarkan hasil eksperimen diperoleh model terbaik dari pemilihan parameter pada Back Propagation Neural Network yaitu input layer 32, jumlah nueron pada hidden layer $=19$, learning rate $=0.3$, training cycle $=100$, dan momentum 0.2 . Arsitektur Back Propagation Neural Network diilustrasikan pada Gambar 2.

\section{Family Sciaenidae}

Family Sciaenidae terdiri dari 5 spesies, yaitu Dendrophysa Russeli, Otolithes Ruber, Panna Microdon, Johnius Belangerii, dan Johnius Carouna. Dendrophysa Russeli, Otolithes Ruber, Panna Microdon yang setiap spesies memiliki 29 citra, sedangkan Johnius Belangerii, Johnius Carouna memiliki 28 citra pada setiap spesiesnya, sehingga total keseluruhan untuk family Sciaenidae sebanyak 143 citra.

\section{Segmentasi Citra menggunakan Threshold 0,4}

Hasil eksperimen segmentasi citra menggunakan threshold dengan nilai 0.4 , diperoleh akurasi sebesar $95 \%$, seperti data confusion matrik pada tabel 2:

Tabel 2: Confussion matrix family Sciaenidae (Threshold 0,4)

\begin{tabular}{|c|c|c|c|c|c|c|}
\hline & $\begin{array}{c}\text { true } \\
\text { DenRus }\end{array}$ & $\begin{array}{c}\text { true } \\
\text { JohBel }\end{array}$ & $\begin{array}{c}\text { true } \\
\text { JohCar }\end{array}$ & $\begin{array}{c}\text { true } \\
\text { OtoRub }\end{array}$ & $\begin{array}{c}\text { true } \\
\text { PanMic }\end{array}$ & $\begin{array}{c}\text { class } \\
\text { precision }\end{array}$ \\
\hline $\begin{array}{c}\text { pred. } \\
\text { DenRus }\end{array}$ & 27 & 0 & 0 & 1 & 0 & $96.7 \%$ \\
\hline $\begin{array}{c}\text { pred. } \\
\text { JohBel }\end{array}$ & 2 & 27 & 2 & 0 & 0 & $93.3 \%$ \\
\hline $\begin{array}{c}\text { pred. } \\
\text { johCar }\end{array}$ & 0 & 1 & 26 & 0 & 0 & $100.0 \%$ \\
\hline $\begin{array}{c}\text { pred. } \\
\text { OtoRub }\end{array}$ & 0 & 0 & 0 & 28 & 0 & $100.0 \%$ \\
\hline $\begin{array}{c}\text { pred. } \\
\text { PanMic }\end{array}$ & 0 & 0 & 0 & 0 & 29 & $100.0 \%$ \\
\hline class recall & $92.0 \%$ & $96.6 \%$ & $92.9 \%$ & $96.6 \%$ & $100.0 \%$ & \\
\hline
\end{tabular}

Akurasi $=$

Iumlah datayang diprediks benar

Tumlah data uji

$$
\begin{aligned}
& =\frac{136}{143} \times 100 \% \\
& =95 \%
\end{aligned}
$$

\section{Segmentasi Citra menggunakan Otsu Threshold}

Tiga spesies dalam family ini yaitu Dendrophysa Russeli, Johnius Belangerii, dan Panna Microdon diprediksi $100 \%$ benar. Dua data dari spesies Johnius Carouna diprediksi salah sebagai Johnius Belangerii dan satu data dari spesies Otolithes Ruber diprediksi salah sebagai Dendrophysa Russeli.
Diperoleh hasil akurasi sebesar 98\%, seperti data confusion matrix pada tabel 3:

Tabel 3: Confussion matrix family Sciaenidae (Otsu Threshold)

\begin{tabular}{|l|c|c|c|c|c|c|}
\hline & $\begin{array}{c}\text { true } \\
\text { DenRus }\end{array}$ & $\begin{array}{c}\text { true } \\
\text { JohBel }\end{array}$ & $\begin{array}{c}\text { true } \\
\text { JohCar }\end{array}$ & $\begin{array}{c}\text { true } \\
\text { OtoRub }\end{array}$ & $\begin{array}{c}\text { true } \\
\text { PanMic }\end{array}$ & $\begin{array}{c}\text { class } \\
\text { precision }\end{array}$ \\
\hline $\begin{array}{l}\text { pred. } \\
\text { DenRus }\end{array}$ & 29 & 0 & 0 & 1 & 0 & $96.7 \%$ \\
\hline $\begin{array}{l}\text { pred. } \\
\text { JohBel }\end{array}$ & 0 & 28 & 2 & 0 & 0 & $93.3 \%$ \\
\hline $\begin{array}{l}\text { pred. } \\
\text { JohCar }\end{array}$ & 0 & 0 & 26 & 0 & 0 & $100.0 \%$ \\
\hline $\begin{array}{l}\text { pred. } \\
\text { OtoRub }\end{array}$ & 0 & 0 & 0 & 28 & 0 & $100.0 \%$ \\
\hline $\begin{array}{l}\text { pred. } \\
\text { PanMic }\end{array}$ & 0 & 0 & 0 & 0 & 29 & $100.0 \%$ \\
\hline $\begin{array}{l}\text { class } \\
\text { recall }\end{array}$ & $100 \%$ & $100 \%$ & $92.9 \%$ & $96,6 \%$ & $100 \%$ & \\
\hline
\end{tabular}

Akurasi $=$

Iumlah datayang diprediks benar Tumlah data uji

$$
\begin{aligned}
& =\frac{140}{143} \times 100 \% \\
& =98,00 \%
\end{aligned}
$$

\section{Family Ariidae}

Family Ariidae terdiri dari 6 spesies yaitu Nemapteryx Caelata, Arius Maculatus, Cryptarius Truncatus, Hexanemathictys Sagor, Osteogeneiosus Militaris, dan Plicofollis Argyropleuron, setiap spesies memiliki 28 citra sehingga total Family Ariidae memiliki 168 citra.

\section{Segmentasi Citra menggunakan Threshold 0,4}

Hasil eksperimen segmentasi citra menggunakan threshold dengan nilai 0.4, diperoleh akurasi sebesar $52 \%$, seperti data confusion matrik seperti tabel 4:

Tabel 4: Confussion matrix family Ariidae Threshold 0,4

\begin{tabular}{|c|c|c|c|c|c|c|}
\hline & $\begin{array}{c}\text { true } \\
\text { Nemcae }\end{array}$ & $\begin{array}{c}\text { true } \\
\text { AriMac }\end{array}$ & $\begin{array}{c}\text { true } \\
\text { CryTru }\end{array}$ & $\begin{array}{c}\text { true } \\
\text { HexSag }\end{array}$ & $\begin{array}{c}\text { true } \\
\text { OstMil }\end{array}$ & $\begin{array}{c}\text { true } \\
\text { PliArg }\end{array}$ \\
\hline $\begin{array}{c}\text { Pred. } \\
\text { Nemcae }\end{array}$ & 17 & 2 & 3 & 0 & 4 & 0 \\
\hline $\begin{array}{c}\text { pred. } \\
\text { AriMac }\end{array}$ & 2 & 20 & 0 & 3 & 0 & 0 \\
\hline $\begin{array}{c}\text { pred. } \\
\text { CryTru }\end{array}$ & 4 & 2 & 19 & 2 & 2 & 1 \\
\hline $\begin{array}{c}\text { pred. } \\
\text { HexSag }\end{array}$ & 0 & 3 & 3 & 18 & 2 & 2 \\
\hline $\begin{array}{c}\text { pred. } \\
\text { OstMil }\end{array}$ & 2 & 1 & 2 & 3 & 21 & 3 \\
\hline $\begin{array}{c}\text { pred. } \\
\text { PliArg }\end{array}$ & 1 & 0 & 1 & 2 & 0 & 20 \\
\hline
\end{tabular}

Akurasi $=$

Iumlah datayang diprediks benar $\mathrm{x} 100 \%$

$$
\begin{aligned}
& \text { Iumlah data uji } \\
& =\frac{88}{168} \times 100 \% \\
& =\mathbf{5 2} \%
\end{aligned}
$$

\section{Segmentasi Citra menggunakan Otsu Threshold}

Dua spesies yaitu Hexanemathictys Sagor dan Plicofollis Argyropleuron diprediksi 100\% benar. 
Kesalahan prediksi terjadi pada empat spesies yang lain yaitu Nemapteryx Caelata diprediksi 9 kali kesalahan, Arius Maculatus diprediksi 5 kali kesalahan, Cryptarius Truncatus diprediksi 6 kali kesalahan, dan Osteogeneiosus Militaris diprediksi 4 kali kesalahan. Diperoleh hasil akurasi sebesar $85,7 \%$ seperti ditampilkan data confusion matrix pada tabel 5:

Tabel 5: Confussion matrix family Ariidae (Otsu Threshold)

\begin{tabular}{|c|c|c|c|c|c|c|}
\hline & $\begin{array}{c}\text { true } \\
\text { Nemcae }\end{array}$ & $\begin{array}{c}\text { true } \\
\text { AriMac }\end{array}$ & $\begin{array}{c}\text { true } \\
\text { CryTru }\end{array}$ & $\begin{array}{c}\text { true } \\
\text { HexSag }\end{array}$ & $\begin{array}{c}\text { true } \\
\text { OstMil }\end{array}$ & $\begin{array}{c}\text { true } \\
\text { PliArg }\end{array}$ \\
\hline $\begin{array}{c}\text { Pred. } \\
\text { Nemcae }\end{array}$ & 19 & 2 & 3 & 0 & 4 & 0 \\
\hline $\begin{array}{c}\text { pred. } \\
\text { AriMac }\end{array}$ & 2 & 23 & 0 & 0 & 0 & 0 \\
\hline $\begin{array}{c}\text { pred. } \\
\text { CryTru }\end{array}$ & 4 & 2 & 22 & 0 & 0 & 0 \\
\hline $\begin{array}{c}\text { pred. } \\
\text { HexSag }\end{array}$ & 0 & 0 & 0 & 28 & 0 & 0 \\
\hline $\begin{array}{c}\text { pred. } \\
\text { OstMil }\end{array}$ & 2 & 1 & 2 & 0 & 24 & 0 \\
\hline $\begin{array}{c}\text { pred. } \\
\text { PliArg }\end{array}$ & 1 & 0 & 1 & 0 & 0 & 28 \\
\hline
\end{tabular}

Akurasi $=$

$\frac{\text { Iumlah datayang diprediks benar }}{\text { Iumlah data uji }} \times 100 \%$

$$
\begin{aligned}
& =\frac{144}{168} \times 100 \% \\
& =85,7 \%
\end{aligned}
$$

\section{Family Engraulidae}

Family Engraulidaeterdiri dari 3 spesies yaitu Coilia Dussumieri, Setipinna Taty, dan Thryssa Hamiltonii, setiap spesies memiliki 30 citra dengan total Family Engraulidae sebanyak 90 citra.

\section{Segmentasi Citra menggunakan Threshold 0,4}

Hasil eksperimen segmentasi citra menggunakan threshold dengan nilai 0.4 , diperoleh akurasi sebesar $57,68 \%$, seperti data confusion matrik pada tabel 6 :

Tabel 6: Confussion matrix family Ariidae dengan

\begin{tabular}{|c|c|c|c|c|}
\hline & $\begin{array}{c}\text { true } \\
\text { Colia }\end{array}$ & $\begin{array}{c}\text { true } \\
\text { Setipinna }\end{array}$ & $\begin{array}{c}\text { true } \\
\text { Thryssa }\end{array}$ & $\begin{array}{c}\text { class } \\
\text { precision }\end{array}$ \\
\hline $\begin{array}{c}\text { pred. } \\
\text { Colia }\end{array}$ & 24 & 3 & 5 & $75.00 \%$ \\
\hline $\begin{array}{c}\text { pred. } \\
\text { Setipinna }\end{array}$ & 2 & 25 & 3 & $83.33 \%$ \\
\hline $\begin{array}{c}\text { pred. } \\
\text { Thryssa }\end{array}$ & 4 & 5 & 22 & $78.57 \%$ \\
\hline $\begin{array}{c}\text { class } \\
\text { recall }\end{array}$ & $80.00 \%$ & $73.33 \%$ & $73.33 \%$ & \\
\hline
\end{tabular}

$$
\begin{aligned}
\text { Akurasi }= & \frac{\text { [umlah data yang diprediks benar }}{\text { Tumlah data }} \times 100 \% \\
& =\frac{52}{90} \times 100 \% \\
& =57,8 \%
\end{aligned}
$$

\section{Segmentasi Citra menggunakan Otsu Threshold}

Spesies Coilia Dussumieri diprediksi 6 kali kesalahan, Setipinna Taty diprediksi 5 kali kesalahan, dan Thryssa Hamiltonii diprediksi 8 kali kesalahan. Diperoleh hasil akurasi sebesar 78,89\% seperti ditampilkan data confusion matrix pada tabel 7:

Tabel 7: Confussion matrix family Ariidae ( Otsu Threshold)

\begin{tabular}{|c|c|c|c|c|}
\hline & $\begin{array}{c}\text { true } \\
\text { Colia }\end{array}$ & $\begin{array}{c}\text { true } \\
\text { Setipinna }\end{array}$ & $\begin{array}{c}\text { true } \\
\text { Thryssa }\end{array}$ & $\begin{array}{c}\text { class } \\
\text { precision }\end{array}$ \\
\hline $\begin{array}{c}\text { pred. } \\
\text { Colia }\end{array}$ & 24 & 3 & 5 & $75.00 \%$ \\
\hline $\begin{array}{c}\text { pred. } \\
\text { Setipinna }\end{array}$ & 2 & 25 & 3 & $83.33 \%$ \\
\hline $\begin{array}{c}\text { pred. } \\
\text { Thryssa }\end{array}$ & 4 & 2 & 22 & $78.57 \%$ \\
\hline $\begin{array}{c}\text { class } \\
\text { recall }\end{array}$ & $80.00 \%$ & $83.33 \%$ & $73.33 \%$ & \\
\hline
\end{tabular}

Akurasi $=$

$\frac{\text { Tumlah data yang diprediks benar }}{\text { Tumlah data uji }} \times 100 \%$

$$
\begin{aligned}
&=\frac{71}{90} \times 100 \% \\
&=79,8 \%
\end{aligned}
$$

\section{Semua Family}

Semua family terdiri dari 14 spesies yaitu Dendrophysa Russeli, Otolithes Ruber, Panna Microdon, Nemapteryx Caelata, Arius Maculatus, Cryptarius Truncatus, Hexanemathictys Sagor, Osteogeneiosus Militaris, Plicofollis Argyropleuron, Johnius Belangerii, Johnius Carouna, Coilia Dussumieri, Setipinna Taty, dan Thryssa Hamiltonii, setiap spesies memiliki 28 citra dengan total semua family sebanyak 392 citra.

\section{Segmentasi Citra menggunakan Threshold}

Hasil klasifikasi pada segmentasi citra menggunakan threshold dengan nilai 0.4 , diperoleh akurasi sebesar 82,4\%. Data confusion matrik seperti tabel 7:

Segmentasi Citra menggunakan Otsu Threshold

Hasil klasifikasi pada segmentasi citra menggunakan Otsu Threshold dengan nilai threshold antara 0,2 hingga 0,4 diperoleh akurasi sebesar 94,9\% lebih tinggi dibandingkan dengan segmentasi menggunakan threshold 0,4. Data confusion matrik seperti tabel 8:

$$
\begin{aligned}
\text { Akurasi }= & \frac{\text { [umlah data yang diprediks benar }}{\text { Jumlah datauji }} \times 100 \% \\
& =\frac{372}{392} \times 100 \% \\
& =94,9 \%
\end{aligned}
$$




\section{Hasil Pengujian}

Proses klasifikasi menggunakan Back Propagation Neural Network (BPNN) berbasis segmentasi threshold 0,4 dengan hasil sebagai berikut: family Sciaenidae diperoleh akurasi sebesar 92\%, family Ariidae diperoleh akurasi sebesar 52\%, family Engraulidae diperoleh akurasi sebesar 58\%, dan semua family diperoleh akurasi sebesar $92 \%$,

Proses klasifikasi menggunakan Back Propagation Neural Network (BPNN) berbasis segmentasi Otsu Threshold dengan hasil sebagai berikut: family Sciaenidae diperoleh akurasi sebesar 98\%, family Ariidae diperoleh akurasi sebesar $86 \%$, family Engraulidae diperoleh akurasi sebesar 79\%, dan semua family diperoleh akurasi sebesar $95 \%$. Perbandingan akurasi berbasis segmentasi threshold 0,4 dan Otsu Threshold dapat dilihat pada tabel 9 .

Tabel 8: Perbandingan akurasi berbasis Threshold 0,4 dan Otsu

\begin{tabular}{|c|c|c|c|}
\hline No. & Family & $\begin{array}{c}\text { Back Propagation } \\
\text { Neural Network } \\
\text { Based on } \\
\text { Threshold 0,4 }\end{array}$ & $\begin{array}{c}\text { Back Propagation } \\
\text { Neural Network } \\
\text { Based on Otsu } \\
\text { Threshold }\end{array}$ \\
\cline { 2 - 4 } 1 & Sciaenidea & $92 \%$ & $97 \%$ \\
\hline 2 & Ariidae & $52 \%$ & $86 \%$ \\
\hline 3 & Engraulidae & $58 \%$ & $80 \%$ \\
\hline 4 & All Family & $65 \%$ & $95 \%$ \\
\hline
\end{tabular}

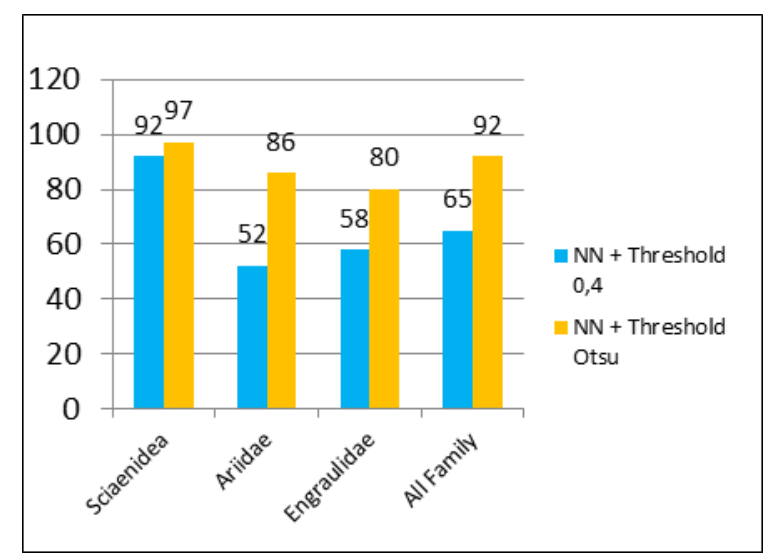

Gambar 4: Perbandingan Akurasi BPNN Threshold 0,4 dan BPNN Otsu Threshold

Dari gambar 4 terlihat jelas bahwa segmentasi menggunakan Otsu threshold menghasilkan akurasi lebih tinggi dibandingkan dengan menggunakan threshold 0,4 . Terjadi peningkatan akurasi, rata-rata sebesar $22 \%$.

Sedangkan, bila dibandingkan dengan penelitian sebelumnya yang dilakukan Nima Salimi et al. menggunakan metode Discriminat Analysis (DA) dengan hasil sebagai berikut: family Sciaenidae diperoleh akurasi sebesar 96\%, family Ariidae diperoleh akurasi sebesar 93\%, family Engraulidae diperoleh akurasi sebesar 97\%, dan semua family diperoleh akurasi sebesar 92\%. Untuk lebih jelasnya dapat dilihat pada tabel 9 :

Tabel 9: Perbandingan akurasi DA dan BPNN

\begin{tabular}{|c|c|c|c|}
\hline No. & Family & $\begin{array}{c}\text { Discriminant } \\
\text { Analysis }\end{array}$ & $\begin{array}{c}\text { BackPropagation } \\
\text { Neural Network } \\
\text { Based on Otsu } \\
\text { Threshold }\end{array}$ \\
\hline 1 & Sciaenidea & $96 \%$ & $97 \%$ \\
\hline 2 & Ariidae & $93 \%$ & $86 \%$ \\
\hline 3 & Engraulidae & $97 \%$ & $80 \%$ \\
\hline 4 & All Family & $92 \%$ & $95 \%$ \\
\hline
\end{tabular}

Berdasarkan tabel 10 diketahui terjadi peningkatan akurasi pada family Sciaenidae dan semua family, namun terjadi penurunan akurasi pada family Ariidae dan Engraulidae.

Grafik perbandingan akurasi menggunakan metode Discriminant Analysis (DA) dan Back Propagation Neural Network (BPNN) dengan Otsu threshold, ditunjukkan oleh gambar 5:

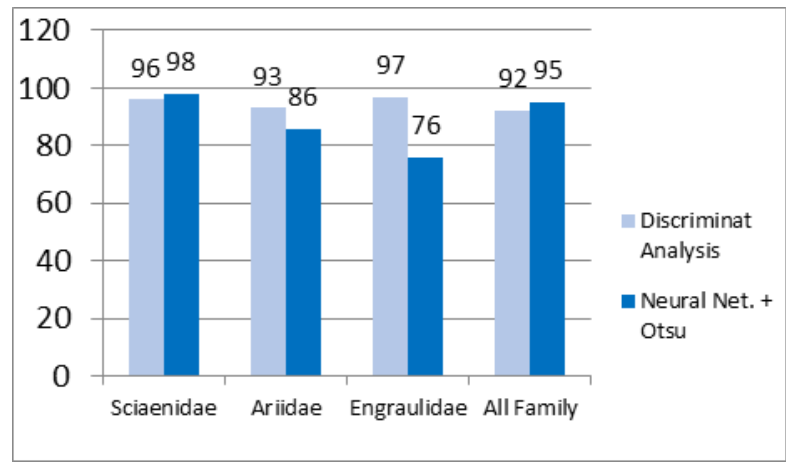

Gambar 5: Perbandingan Akurasi DA dan BPNN

\section{KESIMPULAN}

Hasil eksperimen yang sudah dilakukan pada penelitian ini dapat disimpulkan sebagai berikut:

1. Preprocessing sangat dibutuhkan pada pengolahan citra untuk berbagai tujuan. Penggunaan filtering untuk mengurangi noise (derau) dan segmentasi citra menggunakan metode Otsu untuk menentukan threshold optimal antara obyek dan background, dapat mengurangi kesalahan pada deteksi tepi. Hasil eksperimen menunjukkan bahwa penggunaan segmentasi dengan Otsu threshold mampu meningkatkan akurasi dibandingkan segmentasi dengan threshold 0,4. Terjadi peningkatan akurasi, rata-rata sebesar $22 \%$. Oleh karena itu metode Otsu threshold mampu menentukan threshold yang optimal pada proses pemisahan obyek dan latar belakang.

2. Pengenalan spesies ikan menggunakan metode Backpropagation Neural Network memberikan akurasi sebesar $98 \%$ pada family Sciaenidaele, 
$86 \%$ pada family Ariidae, $79 \%$ pada family Engraulidae, dan $94,88 \%$ pada semua family. Dibandingkan dengan menggunakan metode Discriminant Analysis diperoleh peningkatan akurasi pada family Sciaenidae sebesar $2 \%$ dan pada semua family peningkatan akurasi sebesar $3,04 \%$.

\section{PUSTAKA}

Abdul Kadir, A. S. (2013). Pengolahan Citra, Teori dan Aplikasi. Andi Yogyakarta.

Campana, S. (1999). Chemistry and composition of fish otoliths:pathways, mechanisms and applications. Marine Ecology Progress Series, 188 , 263-297. https://doi.org/10.3354/meps188263

Eko, P. (2014). Data Mining Mengolah Data Menjadi Informasi Menggunakan Matlab. Andi Offset Yogyakarta.

Eko Prasetyo. (2015). Data Mining, Konsep dan Aplikasi.

Fitch, J. E., \& Brownell, R. L. (1968). Fish Otoliths of Cetacean Stomachs and Their Feeding Habits Interpreting, 25(12), 2561-2574.

Kalish, J. M. (1991). Oxygen and carbon stable isotopes in the otoliths of wild and laboratoryreared Australian salmon (Arripis trutta). Marine Biology, 110(1), 37-47. https://doi.org/10.1007/BF01313090

Miloslavich, P. (2012). Census of Marine Life, 56, 155-158.

Panfili, J., de Pontual, H., Troadec, H., \& Wright, P. J. (2002). Manual of Fish Sclerochronology. Ifremer-IRD, 464. https://doi.org/10.1643/OT03-266

Parisi-Baradad, V., \& Manjabacas, A. (2010). Automated Taxon Identification of Teleost fishes using an otolith online databaseAFORO. Fisheries Research, 105(1), 13-20. https://doi.org/10.1016/j.fishres.2010.02.005

Reichenbacher, B. (2007). Combined Otolith Morphology and Morphometry for Assessing Taxonomy and Diversity in Fossil and Extant Killifish. Journal of Morphology, 268(February), 254-274. https://doi.org/10.1002/jmor

Salimi, N., Loh, K. H., Dhillon, S. K., \& Chong, V. C. (2016). Fully-automated identification of fish species based on otolith contour: using short-time Fourier transform and discriminant analysis ( STFT-DA ), 1-15. https://doi.org/10.7717/peerj.1664

Smith, P., Reid, D. B., Environment, C., Palo, L., Alto, P., \& Smith, P. L. (1979). Otsu1975, 20(1), 62-66.
Soria, A., \& Baradad, P. (2012). On the Automatic Detection of Otolith Features for Fish Species Identication and their Age Estimation, (October). 